\title{
The research and exploration on innovative practice with inquiry learning oriented
}

\author{
Wen Jin, Zhao Chunxia, Gu Shaoxuan Huang Xuehui \\ School of Material Science and Engineering, Wuhan University of Technology \\ China Wuhan \\ wen9888@hotmail.com
}

\begin{abstract}
The innovation ability is a primary target of "outstanding engineer" training and inquiry learning is an effective teaching method to cultivate students' innovation ability. Carrying out inquiry learning based on the innovative practice is an exploring direction of excellent talents training. This paper analysed the role of inquiry learning in cultivating innovation ability and put forward the design concept and project about innovative practice, then discussed the ways and methods to enhance and develop students' ability of innovation and practice through the combination of inquiry learning and innovative practice.
\end{abstract}

Keywords-inquiry learning; innovative practice; outstanding engineer; innovation ability

\section{INTRODUCTION}

China is upgrading its growth model and promoting its global competitiveness recently. Engineering talents with international competitiveness who are able to adapt to and support industrial development are essential. "Innovationdriven Development Strategy" is addressed in the report at 18th Party Congress and the cultivation of innovation ability is becoming the key concern in education of high-level engineering talents. "Outstanding Engineer Education Program” is aimed at bringing up a multitude of qualified engineering talents of all types with innovation ability in order to meet the demand of social and economic development. Those talents are called "Outstanding Engineer". The "Outstanding Engineer Education Program" emphasizes the cultivation of innovation ability as well as practical ability. Hence for the purpose of shifting attention from bookish knowledge to multi-dimensional abilities, apart from designing and building a curriculum system, teachers are also obliged to reform the form and methods used in organization of education.

Inquiry learning is a form of teaching that conforms to the law of ability training and the logic of quality formation. Teachers are encouraged to combine the characteristics of inquiry learning with their specific teaching phases and contents to reflect the function of inquiry learning during the course of teaching, thus enhancing students' abilities. This teaching process is a valuable exploration in cultivation of engineering talents.

\section{CHARACTERISTICS OF INQUIRY LEARNING}

Inquiry learning is also called exploratory learning. It refers to the inquiry-based process during which students actively raise questions, analyze problems and solve puzzles under the guidance of teachers. Teaching objectives including knowledge learning and ability cultivation are met through the course. Compared with old-fashioned teaching style, inquiry learning has characteristics such as openness of content, autonomy of students and explorative learning methods.

Openness of content. Traditional teaching focuses on teachers' one-way imparting of knowledge and most of the points are limited to the content of textbooks. Unlike traditional teaching, inquiry learning is a kind of "problem-solving learning”. Students pick their research topics according with course requirements and solve problems during their research. Actual production process is quite complex and could be influenced by multiple factors, so problems related to engineering cannot be solved by merely applying knowledge of one single area. As a result, students have to combine their knowledge from several courses before they could finally complete their research. They are even required to apply knowledge that beyond the contents of textbooks to refine their research.

Autonomy of students. In inquiry learning, teachers create a suitable question context to arouse students' interests. After their investigation desire has been stirred up, students are selfmotivated to research and study with their own open minds. Their initiatives are stimulated and their autonomy comes into play during the course of solving problems. This process is more led by students' active construction than by external stimulus.

Explorative learning methods. In traditional teaching, students mainly rely on passive memory and the process has little initiative involved. On the contrary, inquiry learning is driven by problems of concrete issues in the professional field. Those problems could inspire students' thoughts and act as breakthrough points of their study. Most of the time, problems in traditional learning have exact answers, but that is not the case in inquiry learning. To solve problems that come from real-world practices, students are obliged to use their expertise to consult books, analyze and decompose complexity, design a feasible scheme and carry out research. Their thinking ability, research ability and innovation ability are thus sharpened. 


\section{ROLE OF INQUIRY LEARNING IN CULTIVATION OF INNOVATION ABILITY}

The fundamental elements of innovation ability are innovative conscientiousness, innovative thinking and innovative skills, among which innovative thinking is the core element. In inquiry learning, students are asked to think and study on their own. They aggressively investigate and explore, trying to analyze questions through research and using critical thinking and innovative thinking to solve problems. Encouraging students to mix kinds of thinking modes in their exploration of the unknown could effectively have their innovative thinking trained.

Innovation ability could be exercised and trained through continuously solving practical problems. In inquiry learning, students pick their research topics according with course requirements and implement research in groups to probe into regularities of knowledge and laws of problem-solving methods. This learning process in an open and autonomic environment would arouse students' curiosity, strengthen their independent consciousness, shape their explorative spirits and finally improve their innovative consciousness.

Inquiry learning is a question-based and project-based process within the context of practical issues. Through research and exploration, students gain knowledge together with skills. When facing practical problems arising from real world, students' learning initiatives are to be stimulated. Those problems are more complicated and comprehensive in many terms than problem sets in textbooks. Students should analyze and study those problems with systematic intensive thinking and innovative thinking to find out a feasible solution. Their innovative skills are improved during the course.

These characteristics of inquiry learning create a positive environment for the cultivation of innovation ability.

\section{TEACHING DESIGN AND IMPLEMENTATION OF INQUIRY LEARNING}

\section{A. Teaching Design}

For cultivating innovation ability of outstanding engineering talents, teachers should integrate the cultivation of innovative consciousness into every phase of teaching, following a well-designed teaching plan. Teachers could seek for relevant material that might be compelling to students, create specific question context, offer students options of research fields and then instruct them to form their own research scheme. To better serve its purpose, the question context should be related to practical issues and actual conditions in industry. Also it should be both challenging and achievable for students.

Senior students have already gained fundamental knowledge and specialized skills, so we use the theme of "material designing" and launch technological competitions to carry out inquiry learning. New trends in the field of material science are set as topics of research. Evaluation rules include application of fundamental theory, practical skills, scientific thinking ability and innovation ability, reflecting the characteristics and objectives of inquiry learning.

Competitive teaching activities consist of 7 parts: create the question context-form a research group-choose research topics and design research plans-research plan review-confirm research plan-implement research-presentation and communication-project review. The series of identification, investigation and solution of problems make blending inquiry learning into teaching phases possible. Students are extensively trained in terms in innovation ability and cooperation spirits.

\section{B. Teaching Implementation}

a)Create the question context. Taking into account teaching objectives, new trends in material science and practical issues, teachers create a context under topics of improvement of material property or processing techniques.

b)Form research groups. Students form their research groups of their own free will and elect their group leaders. Within each group, every member has both independent and cooperative tasks. Members in a group work collaboratively to complete their research.

c) Choose research topics and design research plans. In this part research groups are asked to consult books and other types of material to choose their research topics. Members in each group work together to analyze the topic, pick a technique route, determine relevant characterization methods and design their preliminary research plan.

d)Research plan review. Representatives from each group make presentations to communicate their theoretical foundation, train of thought and implementation proposal with other groups and teachers. Other groups could bring forward their opinions and make comments. Teachers remark on the feasibility, rationality, economical efficiency and innovativeness of these research plans. Students' degree of mastering of knowledge, skills of communication and adaptability are tested during the presentations. In the meantime, teachers give advice and offer alternative plans to students regarding any potential obstacle or risk involved in their research plans, helping them refine their plans.

e)Confirm research plan. Based on advice and comments made during the research plan review phase, research groups refine their plans by discussing with teachers and other groups and implementing further studies. Each member apply his or her specialty and attributes to propose ways of improvement. The group leader is responsible for summarizing ideas and forming the final research plan.

f)Implement Research. In this phase, students implement material making and processing methods in their research plan and determine technological parameters taking into account material properties and equipment availability. Then, according to technical route, they carry out research and continuously optimize the scheme during the course. After completing the end product of their material making, students test the properties and performance of the material to ensure that the material meets the objectives. 
g) Project review and evaluation. Students finish their research and submit their final products within the allotted time and make presentations of their making process and material properties. Teachers grade each group considering quality of both the research plan and the final product, and comment on each project as a whole and each student as an individual. Evaluation rules include properties of the material, rationality of the research design, innovativeness, group-work spirit and communication skills.

Research projects related competitive activities are carried out in a phased manner during the whole course of inquiry learning. Evaluation of students is combined with appraisal of individual performance and scores of research plans and final work submitted. The comprehensive assessment of process and results does great help to encouragement of students' innovation ability.

\section{CONCLUSION}

The cultivation of innovation ability is a primary target of "outstanding engineer" training and inquiry learning is an effective teaching method to cultivate students' innovation ability. Inquiry learning aims at cultivating students' innovative and practical skills uses research training as the main method and involves technological competition. This kind of learning method treats students as main subjects and emphasizes on personalized and innovative education. Students could have their innovative consciousness strengthened, innovative thinking stimulated and innovative skills improved. The integration of inquiry learning and innovative practice, and the reflection of characteristics of inquiry learning in the teaching process enable teachers to impart fundamental knowledge and improve students' thinking ability, practical skills and innovation ability.

\section{REFERENCES}

[1] Ministry of education on the implementation of the "The Plan for Educating and Training Outstanding Engineers” several opinions (draft for soliciting opinions)

[2] Lin Jian, Problem/Project Based Learning Orienting to the Cultivation of "Outstanding Engineers" Research in Higher Education of Engineering, 2011, No.6,pp.5-15

[3] Yue Yun-kang, The Application of Research-based Study Teaching Mode in the University Teaching, Educational theory and practice, 2010.Vol.30, No.2,pp.52-54

[4] Leng Cui-ling,Yan Bing,Li zhi-xia,Research on the cultivation of Undergraduate innovation ability based on CDIO concept,Educational Research,2014,No.1,pp.156-157

[5] Chen Ji-ming, On the Cultivation of Scientific Thinking of Innovation practice Course Teaching, Research and Exploration in Laboratory, 2011.Vol.30, No.2,pp.85-87

[6] Yu Shuo, shan Xi-ling, Undergraduate Research Training Program-Effective Practice of Training Innovative Talented,Education for Chinese After-school,2010,No.10,pp.8-9. 